DOI: https://doi.org/10.47405/mjssh.v5i12.570

\begin{tabular}{|c|c|}
\hline 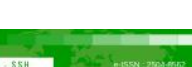 & Malaysian Journal of Social Sciences and Humanities (MJSSH) \\
\hline Malaysian Journal of & Volume 5, Issue 12, December 2020 \\
\hline $\begin{array}{l}\text { Humanities } \\
\text { (MJ-sst) }\end{array}$ & e-ISSN : 2504-8562 \\
\hline & $\begin{array}{l}\text { Journal home page: } \\
\text { www.msocialsciences.com }\end{array}$ \\
\hline
\end{tabular}

\title{
Sorotan Literatur Bersistematik bagi Efikasi Kendiri Pelajar Terhadap Matematik
}

\author{
Siti Nur-Syafiza binti Ahmad Saifi', Mohd Effendi @ Ewan Mohd Matore ${ }^{1}$ \\ ${ }^{1}$ Fakulti Pendidikan, Universiti Kebangsaan Malaysia (UKM) \\ Correspondence: Mohd Effendi @ Ewan Mohd Matore (effendi@ukm.edu.my)
}

\begin{abstract}
Abstrak
Efikasi kendiri merupakan salah satu faktor yang sangat penting dalam penampilan prestasi diri individu dalam semua perkara termasuk pendidikan matematik yang disifatkan sebagai subjek yang sukar. Persaingan sengit dan perubahan teknologi yang pesat memerlukan kepintaran matematik dan wajib diambil hampir dalam kesemua latar belakang pendidikan. Kajian ini menggunakan sorotan literatur bersistematik (SLR) dalam menghasilkan analisis trend efikasi kendiri matematik dalam kalangan pelajar. Tinjauan SLR menerusi analisis trend tahun penerbitan, trend negara kajian dan trend pemboleh ubah perkaitan menerusi fasa utama iaitu merancang menganalisis dan melapor adalah fasa dalam kaedah SLR. Dapatan menunjukkan bahawa bilangan kajian semakin bertambah bermula pada tahun 2015 sehingga tahun 2020. Ini menunjukkan efikasi kendiri pelajar semakin dianggap penting untuk dijadikan pemboleh ubah dalam sesuatu kajian. Trend analisis negara menunjukkan bahawa Amerika Syarikat merupakan negara yang paling banyak melakukan kajian terhadap faktor efikasi kendiri pelajar ini diikuti oleh negara Turkey. Negara-negara lain sangat kurang dalam melakukan kajian untuk efikasi kendiri pelajar khususnya dalam matematik. Trend pemboleh ubah perkaitan yang dilakukan bersama-sama faktor efikasi kendiri dan hadir daripada pelbagai arah seperti faktor dalam, diri sendiri, guru, persekitaran, sekolah dan pentadbiran. Kajian lebih mendalam perlu dilakukan untuk mengkaji faktor lain seperti pemilihan rakan sebaya, tahap pendidikan ibu bapa dan pengalaman pembelajaran terdahulu yang boleh dikaitkan dengan tahap efikasi kendiri pelajar dalam matematik. Cadangan kajian lanjutan yang boleh dilakukan mengenai efikasi kendiri adalah seperti tempoh pembelajaran, kurikulum pendidikan dan pemahaman dalam matematik.
\end{abstract}

Kata kunci: efikasi kendiri, pelajar, matematik, sorotan literatur bersistematik, trend negara, trend tahun penerbitan, trend pemboleh ubah perkaitan

\section{Systematic Literature Review of Students Self Efficacy towards Mathematics}

\begin{abstract}
Self-efficacy is one of the most important factors in the appearance of individual self-performance in all matters including mathematics education which is considered a difficult subject. Intense competition and rapid technological change require mathematical intelligence and must be taken into account in almost all educational backgrounds. This study uses a systematic literature review (SLR) in producing a trend analysis of mathematical self-efficacy among students. SLR review through the analysis of the year of publication, the trend of the country of study and the trend of relevance variables through the main phase of planning to analyze and report are phases in the SLR method. Findings show that the number of studies is increasing starting in 2015 until 2020. This shows that students' selfefficacy is increasingly considered important to be a variable in a study. The trend of national analysis
\end{abstract}


shows that the United States is the country that does the most research on the self-efficacy factor of these students followed by the Turkey. Other countries are very lacking in conducting research for students' self-efficacy especially in mathematics. The trend of relational variables is done along with self-efficacy factors and it comes from various directions such as internal factors, self, teachers, environment, school and administration. More in-depth research needs to be done to examine other factors such as peer selection, parental education level and previous learning experiences that can be linked to students' level of self-efficacy in mathematics. Suggestions for further research that can be done on self-efficacy are such as learning period, educational curriculum and understanding in mathematics.

Keywords: self-efficacy, students, mathematics, systematic review, study country trends, year of publication trends, relational variables trends

\section{Pengenalan}

Kejayaan pembelajaran seorang pelajar dipengaruhi oleh pelbagai faktor, sama ada daripada faktor luaran, dalaman serta persekitaran. Faktor luaran dapat dilihat daripada sokongan orang-orang sekeliling, persekitaran dan kemudahan pembelajaran. Faktor dalaman pula adalah seperti ketakutan, keinginan, keyakinan dan kebimbangan terhadap sesuatu perkara. Tanpa disedari, faktor luaran juga boleh mempengaruhi faktor dalaman dalam menentukan kejayaan pembelajaran seseorang pelajar. Terdapat banyak faktor dalam yang telah dibincangkan dan dikaji seperti emosi pembelajaran (Haciomeroglu, 2019), minat dan pencapaian (Rakoczy et al., 2019), konsep kendiri dan kebimbangan (Kaskens, Segers, Goei, van Luit, \& Verhoeven, 2020), kepercayaan diri (Morán-Soto \& Benson, 2018; Yıldız, Çiftçi, \& Özdemir, 2019), prestasi pembelajaran, tingkah laku dan sikap (Morán-Soto \& Benson, 2018). Namun begitu, salah satu faktor menjadi penyumbang dominan dan sering mendapat perhatian pengkaji ialah efikasi kendiri.

Efikasi kendiri merupakan salah satu faktor dalaman diri seseorang pelajar yang menjadi penentu kejayaan seseorang pelajar. Efikasi kendiri didefinisikan sebagai keyakinan diri dan kepercayaan terhadap keupayaan seorang terhadap perbuatannya dalam menyelesaikan sesuatu organisasi (Bandura 1995). Bandura (1997) juga menjelaskan bahawa jika individu yang mempunyai tahap efikasi yang tinggi menjurus kepada mempunyai motivasi yang tinggi dan cekal apabila menghadapi tugasan yang lebih sukar dan mencabar. Dengan erti kata lain, mereka terus bersemangat dan tidak mudah berputus asa. Terdapat empat aspek sumber yang mempengaruhi pembinaan efikasi kendiri seseorang iaitu pengalaman prestasi peribadi, pembelajaran secara pemerhatian, galakan sosial dan rangsangan psikologi serta emosi.

Kajian efikasi kendiri telah banyak dilakukan oleh pengkaji lepas dalam pelbagai aspek seperti efikasi kendiri kerjaya (Abidin et al. 2019; Garner et al. 2020; Mullen et al. 2015), pembelajaran (Fadhillah 2013; Mohamad 2015; Ferrell \& Barbera 2015; Zhang et al. 2020) dan sebagainya. Dalam konteks pendidikan, pengkaji terdahulu juga telah melakukan kajian terhadap efikasi kendiri mengenai pengajaran guru (Hariyanti et al. 2020; Perera \& Jennifer 2020; Awanis et al. 2016; Reza 2016; Habila et al. 2016; Zaki \& Umit 2019), dan juga pembelajaran pelajar dalam berbagai-bagai subjek (Zhurad \& Adnan 2016; Farehah \& Sallehudin 2017; Rosna \& Norasmah 2018). Objektif utama dalam penulisan sorotan literatur bersistematik ini adalah untuk mengkaji trend kajian efikasi kendiri pelajar dalam subjek matematik. Trend yang dimaksudkan adalah trend negara kajian, trend tahun penerbitan dan trend pemboleh ubah perkaitan.

Matematik merupakan satu subjek yang wajib diambil oleh semua pelajar dalam semua peringkat pembelajaran. Pendidikan awal matematik bermula dari zaman kanak-kanak lagi dan secara asasnya ia adalah dimulakan dengan aktiviti mengira dan mengenal nombor. Saban hari, pembelajaran matematik meningkat selari dengan perkembangan kognitif kanak-kanak. Apabila memasuki alam persekolahan, matematik adalah menjadi subjek teras. Semakin tinggi tahap pendidikan, pelajar menganggap pembelajaran matematik semakin sukar. 
Laporan daripada Berita Harian bertarikh 12 Mac 2019 melalui kenyataan Dr Maszlee Malik, Menteri Pendidikan ketika itu, Kementerian Pendidikan mendapati jumlah pelajar yang mengambil mata pelajaran yang berasaskan Sains, Teknologi, Kejuruteraan dan Matematik (STEM) semakin merosot saban tahun. Ini secara tidak langsung berkait rapat dengan penurunan minat pelajar terhadap subjek serta akan memberi kesan kepada faktor kecemerlangan pelajar. Pelaporan Pentaksiran Sekolah Rendah (2019), tahap kecemerlangan seseorang pelajar dalam mata pelajaran Matematik adalah bertujuan untuk mengukur keupayaan mengetahui, memahami dan mengaplikasikan operasi matematik, kemahiran menilai dan mencipta, serta keupayaan menyelesaikan masalah harian secara sistematik, tepat dan teliti. Kecemerlangan pelajar dalam matematik juga dibantu oleh faktor efikasi kendiri yang tinggi.

Pelajar yang mempunyai kepercayaan dan efikasi kendiri yang tinggi sangat membantu serta berpeluang untuk memperoleh tahap kecemerlangan yang tinggi (Alhadabi \& Karpinski, 2020; Rakoczy et al., 2019; Schöber, Schütte, Köller, McElvany, \& Gebauer, 2018; Wang, Liang, Lin, \& Tsai, 2017). Apabila mereka merasakan diri adalah kreatif, secara tidak langsung akan membina efikasi kendiri tinggi (Regier \& Savic, 2020). Aspirasi pendidikan serta efikasi kendiri pelajar akan menjadi positif secara tidak langsung hasil daripada motivasi yang berkesan (Liu et al., 2020; Morán-Soto \& Benson, 2018). Efikasi kendiri yang tinggi dalam pendidikan matematik juga diperoleh daripada pengalaman lepas pelajar itu sendiri. Apabila mereka telah memperoleh kejayaan dan kecemerlangan di peringkat yang rendah sebelum ini, maka keyakinan mereka masih berada di kemuncak apabila menaiki sistem pembelajaran yang lebih tinggi (Morán-Soto \& Benson, 2018; Tustyaningsih, Sulistyono \& Jatmiko, 2017).

Selain daripada faktor dalaman pelajar untuk meningkatkan efikasi kendiri, faktor sokongan dan pengajaran guru juga membantu untuk meningkatkan tahap efikasi kendiri pelajar dalam subjek matematik. Guru yang mempunyai keyakinan dalam pengajaran serta memberi sokongan positif kepada pelajar akan meningkatkan efikasi kendiri pelajar (King-Sears \& Strogilos, 2020). Efikasi kendiri pelajar yang tinggi dalam diri pelajar juga mempengaruhi kemampuan mereka untuk menyelesaikan masalah matematik yang lebih tinggi, sukar dan susah yang mempengaruhi kebebasan belajar mereka untuk melakukan penyelesaian masalah matematik (Nirwana, Tiro \& Sanusi, 2018).

Dalam meramal faktor mempengaruhi tahap efikasi kendiri pelajar dan mengkaji kesan efikasi kendiri pelajar dalam pendidikan matematik, lebih ramai pengkaji lepas melakukan kajian terhadap efikasi kendiri ini. Justeru, objektif utama dalam penulisan sorotan literatur bersistematik ini adalah untuk mengkaji trend negara, trend tahun penerbitan dan trend pemboleh ubah perkaitan bagi kajian efikasi kendiri pelajar dalam subjek matematik.

\section{Metod Kajian}

Sorotan literatur bersistematik (SLR) dalam kajian ini adalah untuk mengatasi penyataan masalah dengan mengenal pasti, menilai secara kritis dan mengintegrasikan penemuan semua kajian terdahulu yang relevan dan berkualiti untuk menjawab satu atau lebih persoalan kajian (Andy 2010). Dalam kajian ini, semua artikel yang melibatkan efikasi kendiri pelajar terhadap matematik dikenal pasti. Hasil daripada kajian sorotan literatur bersistematik ini akan mengenal pasti trend kajian terhadap efikasi kendiri pelajar dalam pelajaran matematik terdahulu.

\section{Strategi Pencarian}

Proses pencarian artikel yang berkaitan adalah dengan menggunakan empat jenis pangkalan data akademik iaitu SCOPUS, Science Direct, ERIC dan Google Scholar. Pengkalan data ini digunakan kerana ia merangkumi kesemua artikel jurnal dan prosiding yang dikumpul daripada pelbagai pautan yang berbeza. Rajah 1 menunjukkan proses pemilihan yang selari dengan kaedah disarankan oleh Karabulut-Ilgu, Jaramillo Cherrez \& Jahren (2018). Kata kunci yang digunakan adalah "self efficacy mathematics" dan "self efficacy mathematics student" dalam Bahasa Inggeris. Manakala dalam Bahasa Melayu kata kunci yang digunakan adalah "efikasi kendiri matematik" digunakan untuk proses 
pencarian. Selain itu, pencarian artikel yang berkaitan dengan efikasi kendiri telah dihadkan untuk tempoh 2015 sehingga 2020 bagi mendapatkan artikel yang terkini.

\section{Kriteria Pemilihan}

Bagi mendapatkan artikel yang tepat dan bersesuaian dengan objektif, beberapa langkah diambil bagi proses penapisan kesemua artikel yang diperoleh seperti yang ditunjukkan dalam Rajah 1. Proses saringan yang pertama adalah berdasarkan beberapa kriteria penerimaan dan penolakan. Kriteria penolakan dalam proses saringan artikel adalah seperti 1) jurnal atau prosiding yang melibatkan mata pelajaran selain matematik, 2) kajian yang dilakukan terhadap selain daripada pelajar, 3) artikel daripada bahasa asing selain Bahasa Melayu, Bahasa Inggeris dan Bahasa Indonesia, dan 4) artikel terbitan tahun 2014 dan sebelumnya. Penerimaan artikel apabila ia memenuhi kriteria seperti 1) terdapat kesemua kata kunci yang digunakan, 2) kajian dilakukan ke atas pelajar, dan 3) artikel Bahasa Melayu, Bahasa Inggeris dan Bahasa Indonesia.

Langkah kedua untuk penyingkiran artikel adalah apabila mendapati artikel yang sama dan berulang walaupun daripada pangkalan data yang berbeza. Ia dapat dilihat melalui pembacaan tajuk, tahun penerbitan serta abstrak. Dan akhir sekali, analisis dilakukan melalui pembacaan penuh dan mendalam terhadap artikel yang tertinggal. Artikel yang tidak berkaitan juga turut dikeluarkan daripada senarai artikel terpilih. Setelah melalui setiap proses pemilihan artikel, daripada 2284 artikel hanya 30 artikel yang dipilih dalam kajian ini (Jadual 1).

Rajah 1: Proses pemilihan artikel dia da ptasi daripa da Kara bulut-Ilgu, Jara millo Cherrez, \& Jahren (2018)

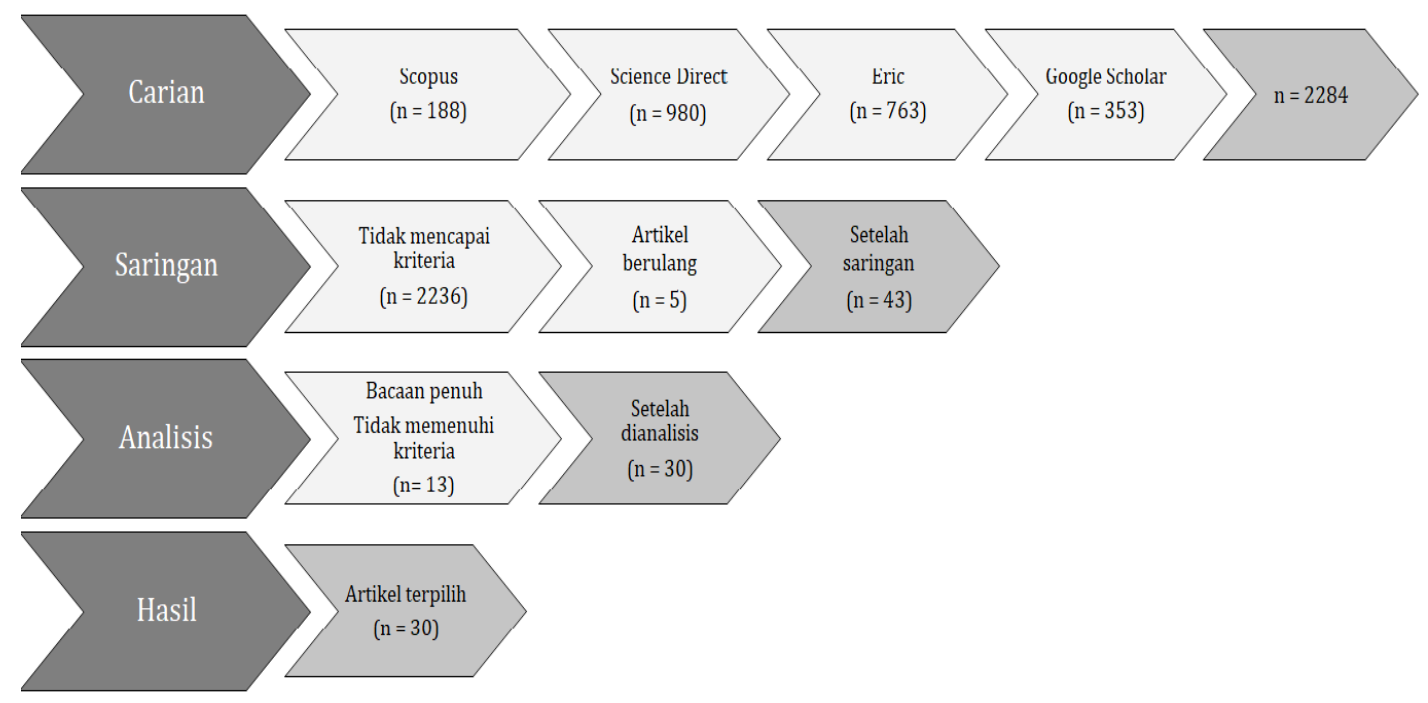

\section{Hasil dan Perbincangan Kajian}

Objektif utama kajian ini dilakukan adalah untuk mengenal pasti trend penyelidikan terdahulu mengenai efikasi kendiri pelajar terhadap matapelajaran matematik. Artikel-artikel terpilih yang digunakan dalam kajian ini adalah kajian yang dilakukan oleh pengkaji dalam tempoh 5 tahun terkini, iaitu kajian daripada tahun 2015 sehingga tahun 2020. Ini adalah kerana kajian terhadap efikasi kendiri pelajar dalam matematik sentiasa dilakukan setiap tahun. Peserta kajian bagi kesemua kajian ini merupakan pelajar daripada pelbagai lapisan seperti pelajar sekolah rendah, menengah, kolej dan universiti. Pelajar-pelajar ini juga merangkumi pelajar lelaki dan perempuan, pelajar kejuruteraan, pelajar teknik vokasional dan pelajar kejururawatan. Selain itu trend yang diambil kira dalam kajian ini adalah trend negara kajian, trend tahun penerbitan dan trend pemboleh ubah perkaitan yang melakukan kajian terhadap efikasi pelajar dalam subjek matematik.

$$
\text { Ja dual1: Gambaran keseluruhan kajian }
$$




\begin{tabular}{ccl}
\hline Penulis \& Tahun & Negara & \multicolumn{1}{c}{ Tajuk Artikel } \\
\hline Sonia et al. (2020) & Mexico & $\begin{array}{l}\text { Measurement Model and Adaptation of A Self-Efficacy Scale } \\
\text { For Mathematics In University Students }\end{array}$ \\
Yasemin (2020) & Turkey & $\begin{array}{l}\text { Middle School Students Perceptions of Their Self efficacy In } \\
\text { Visual Mathematics And Geometry: A Study Of Sixth To } \\
\text { Eighth Grade Pupils In IstanbulProvince, Turkey }\end{array}$ \\
& \\
\hline
\end{tabular}

Hui L.et al. (2020) China

Diana P. et al. (2020)

Paul R. \& Milos S. (2020)

United States

Netherlands

Effects of Digital Learning Materia ls on Nursing Students'

Mathematics Learning, Self-efficacy, and Task Value in

VocationalEducation

How Tea ching to Foster Mathematical Creativity May Impact Student Self-Efficacy For Proving

Impact of Children's Math Self-Concept, Math Self-Efficacy,

Jarise K. et al. (2020)

Tour L. et al. (2020)

Lia E. S. et al. (2020)

José M. T. et al. (2019)

Jie G. (2019)

AmalA. \& Aryn C. K. (2019)

Katrin R.et al. (2019)

Examining The Relationships Between Cognitive Activation, Mathematics: A Multi-Level Analysis

Netherlands

Math Anxiety, and TeacherCompetencies On Math

Development

The Effects of Children's Self-Educational Aspiration and SelfEfficacy on Mathematics Achievement: A Moderated Chained Mediation Model

English Learners' Achievement in Mathematics and Science: Examining The Role of Self-Efficacy

The Effects of Self-Effica cy, Hope, And Enga gement on The Academic Achievement of Secondary Educationin The Dominican Republi

United Sources of Mathematics Self-Efficacy In Chinese Students: A Kingdom Mixed-Method Study with Q-Sorting Procedure

Grit, Self-Efficacy, Achievement Orientation Goals and Academic Performance in University Students

Formative Assessment in Mathematics: Mediated by Feedback's Perceived Usefulness and Students' Self-Efficacy 
Guney H. (2019) Turkey $\quad \begin{aligned} & \text { The Rela tionship Between Elementary Students'Achievement } \\ & \text { Emotions and Sources of Mathematics Self-Efficacy }\end{aligned}$

Pinar Y., \& Elif Y. (2019)

Turkey

Linda G. et al. (2019)

Australia
Mathematics Self-Efficacy Beliefs and Sources of SelfEfficacy: A Descriptive Study with Two Elementary School Students

The Influence of Mathematics Self-Efficacy on Numeracy Performance in First-Year Nursing Students: A Quasi Experimental Study
Christian S. et al. (2018)

German

Gustavo M.\& Lisa

B. (2018)

Margaret E. \& Vasilis S. (2018)

Xia oxia H. et al. (2018)

Julia R. \& Tobias R. (2018)

Ya-LingWang et al. (2017)

Melissa D. (2017) United States

Ayse S. \& Fatma A. (2017)

German
ReciprocalEffects Between Self-Efficacy and Achievement in Mathematics and Rea ding

Relationship of Mathematics Self-Effica cy and Competence United States With Beha viors and Attitudes of Engineering Students with Poor Mathematics

Penga ruh Kema mpuan Berpikir Divergen dan Efikasi Diri Terha dap Presta si Belajar Ma tematika Mela lui Kemandirian BelajarSiswa Kelas VIII SMP Negeri Di Galesong Utara, Kabupaten Takalar

An Exploratory Study of Self-Efficacy, SchoolBelongingness, United States and Co-Teaching Perspectives From Middle School Students and Teachers in A Mathematics Co-Taught Classroom

Impact of Math Self-Efficacy, Math Anxiety, and Growth United States Mindset on Math and Science Career Interest For Middle School Students: The GenderModerating Effect

Students' Math Performance in Higher Education: Exa mining The Role of Self-regulated Learning and Self-Efficacy

Identifying Taiwanese Junior-High School Students'

Taiwan Mathematics Learning Profiles and Their Roles in Mathematics Learning Self-Efficacy and Academic Performance

The Effect of Project-Based Lea rning on Student Self-Efficacy in A DevelopmentalMathematics Course

The Relationship Between Tea cher Efficacy, and Students' Trigonometry Self-Efficacy And Achievement 
Linda R. et al. (2017)

Senol R.et al. (2017)

Gonca U. H. (2016) Turkey

Yin Wu (2016) United States
Analysis of Student And SchoolLevel Variables Related To Mathematics Self-Efficacy LevelBa sed on PISA 2012 Results For China-Shanghai, Turkey, And Greece

Sources of Self-Efficacy of Community College Students Enrolled In Developmental Mathematics

Investiga ting Self-Efficacy, Anxiety, Attitudes and Mathematics Achievement Regarding Gender and SchoolType

Universal Beliefs and Specific Practices: Students' Math SelfEfficacy And Related Factors in The United States and China
Examining Rela tionships a mong Elementary Mathematics Teachers' Effica cy and Their Students' Mathematics Selfefficacy and Achievement

Relations between OperationalChemistry and Physics Problems Solving Skills and Mathematics Literacy Self-Efficacy of Engineering Faculty Students

Jadual 1 menunjukkan secara ringkas nama penulis, tahun penerbitan, negara dan tajuk 30 artikel yang terpilih. Hasil mendapati, pelajar yang terlibat dalam kajian lepas adalah pelajar kolej dan universiti turut menjadi peserta kajian yang dinyatakan dalam penulisan artikel yang dipilih.

\section{Trend Negara Kajian}

Jadual 2 menunjukkan kesemua negara yang terlibat dalam kajian mengenai efikasi kendiri pelajar terhadap subjek Matematik. Secara keseluruhannya, sebanyak 11 buah negara yang menjalankan kajian ke atas faktor ini iaitu Amerika Syarikat (9 kajian), Turkey (7 kajian), German (3 kajian), China (2 kajian), Netherland (2 kajian), Taiwan (2 kajian), United Kingdom (1 kajian), Spain (1 kajian), Mexico (1 kajian), Indonesia (1 kajian), dan Australia (1 kajian).

Amerika Syarikat merupakan negara yang paling banyak melakukan kajian mengenai efikasi kendiri pelajar terhadap subjek Matematik sepanjang lima tahun terkini, tetapi secara puratanya hanya melakukan kajian sebanyak dua kali setahun. Pengkaji dari Turkey adalah negara kedua terbanyak yang melakukan kajian efikasi kendiri pelajar terhadap matematik. Negara tersebut juga mempunyai purata sebanyak dua kajian setahun dalam penghasilan artikel kajian mengenai efikasi kendiri pelajar terhadap matematik. Namun begitu, tiada kajian yang dilakukan terhadap pelajar pada tahun 2018 .

Negara lain seperti Netherlands, Mexico, China dan Taiwan melalukan kajian terhadap efikasi kendiri pada tahun 2020. Negara-negara ini tidak melakukan kajian terhadap pemboleh ubah tersebut dalam tahun 2015 sehingga. Manakala negara lain seperti United Kingdom (2019), Spain (2019), Indonesia (2018), German (2018 \& 2019) dan Australia (2018) tidak melakukan kajian ini secara konsisten setiap tahun. 
DOI: https://doi.org/10.47405/mjssh.v5i12.570

Jadua12: Negara kajian dilakukan oleh pengkaji terdahulu mengenaiefika sikendiri pelajarterhadap subjek Matematik

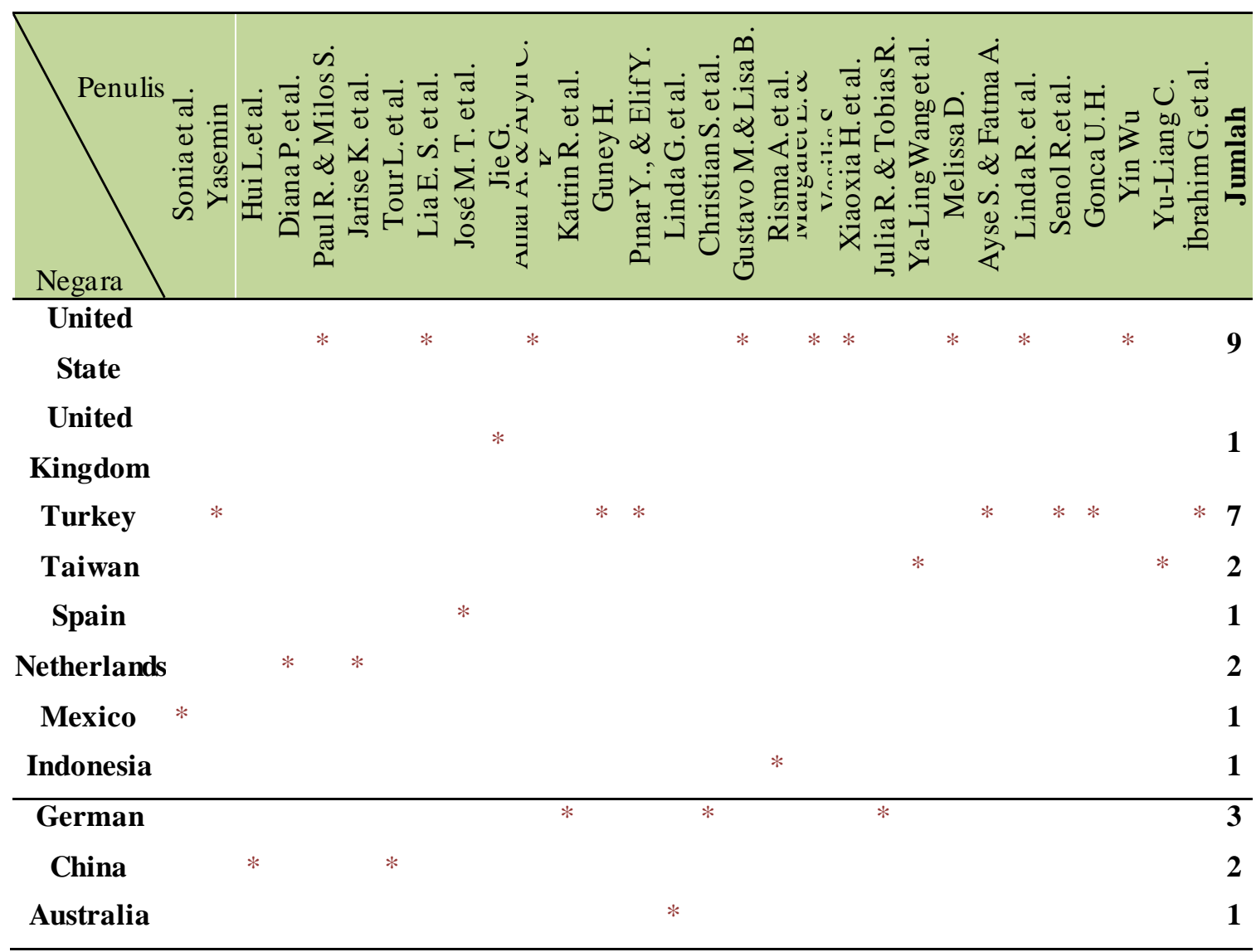

\section{Trend Tahun Kajian}

Jadual 3 menunjukkan trend tahun kajian mengenai efikasi kendiri pelajar terhadap subjek matematik. Tempoh selama 5 tahun terkini termasuk 2020 telah diambil kira. Sehingga Mei 2020, terdapat lapan artikel kajian mengenai faktor efikasi kendiri ini dan ia merupakan tahun yang paling banyak kajian dilakukan. Pada tahun 2019, 2018, dan 2017 masing-masing terdapat tujuh, enam dan lima artikel yang menceritakan kajian terhadap efikasi kendiri pelajar dalam subjek matematik telah dilakukan. Pada tahun 2015 dan 2016, sebanyak dua artikel telah diterbitkan.

Jadual3: Tahun terbitankajian lepas mengenai efika si kendiri pelajarterhadap matematik

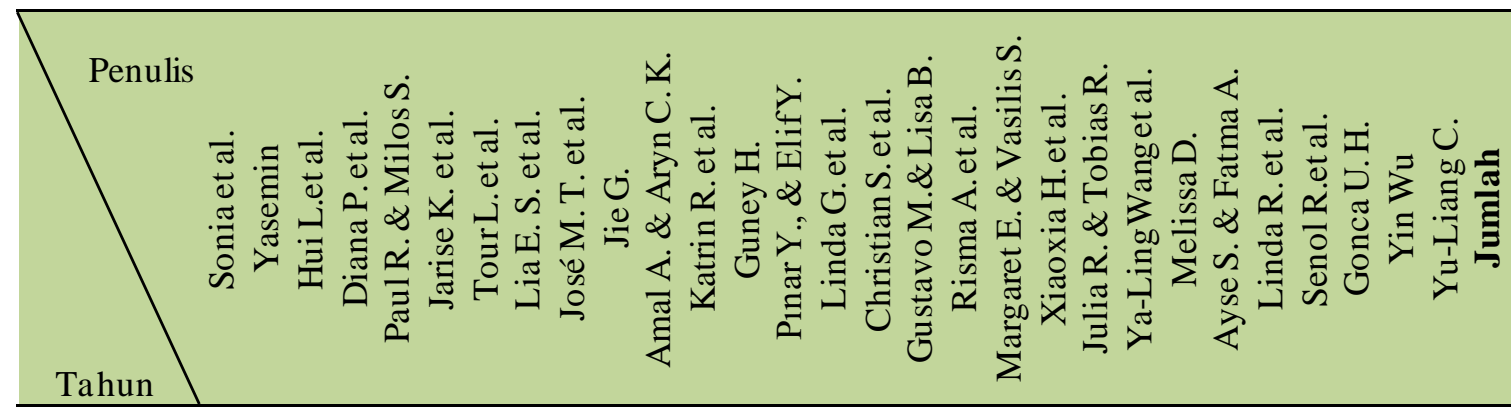

2020 
Trend ini menunjukkan faktor efikasi kendiri pelajar terhadap matematik semakin terkenal dan terbukti melalui bilangan artikel terbitan mengenainya yang semakin banyak saban tahun. Pengkaji akademik mulai sedar bahawa efikasi kendiri mempunyai potensi tinggi dalam memangkinkan kejayaan pelajar dalam bidang matematik.

\section{Trend Pembolehubah Perkaitan}

Jadual 4 merupakan analisis pemboleh ubah yang turut digunakan oleh pengkaji lepas bersama-sama dengan efikasi kendiri pelajar dalam kajian mereka. Sebanyak 14 pemboleh ubah yang telah dikenal pasti dalam bersama-sama menguji tahap efikasi kendiri pelajar terhadap matematik dalam kajian lepas. Faktor lain ini boleh jadi pemboleh ubah bebas ataupun pemboleh ubah bersandar yang menguji tahap efikasi kendiri pelajar terhadap matematik.

Pencapaian akademik pelajar adalah pemboleh ubah yang paling banyak digunakan iaitu sebanyak 14 artikel yang berkaitan. Walaupun ia merupakan pemboleh ubah perkaitan yang paling banyak digunakan, tetapi kajian terhadapnya dilakukan pada tahun berbeza iaitu pada tahun 2020 ( $\mathrm{Li}$, Liu, Zhang, \& Liu; Liu et al.; Sandilos, Baroody, Rimm-Kaufman, \& Merritt,), tahun 2019 (Alhadabi \& Karpinski; Haciomeroglu; Rakoczy et al.,), tahun 2018 (Morán-Soto \& Benson; Schöber, Schütte, Köller, McElvany, \& Gebauer; Nirwana, Tiro \& Sanusi), tahun 2017 (Recber, Isiksal, \& Koc; Wang, Liang, Lin, \& Tsai), tahun 2016 (Wu) dan tahun 2015 (Chang). Pengalaman penguasaan matematik (5 kajian), kebimbangan matematik (4 kajian) serta keyakinan terhadap matematik (4 kajian) adalah pemboleh ubah tertinggi yang dikaitkan dengan efikasi kendiri pelajar dalam analisis ini.

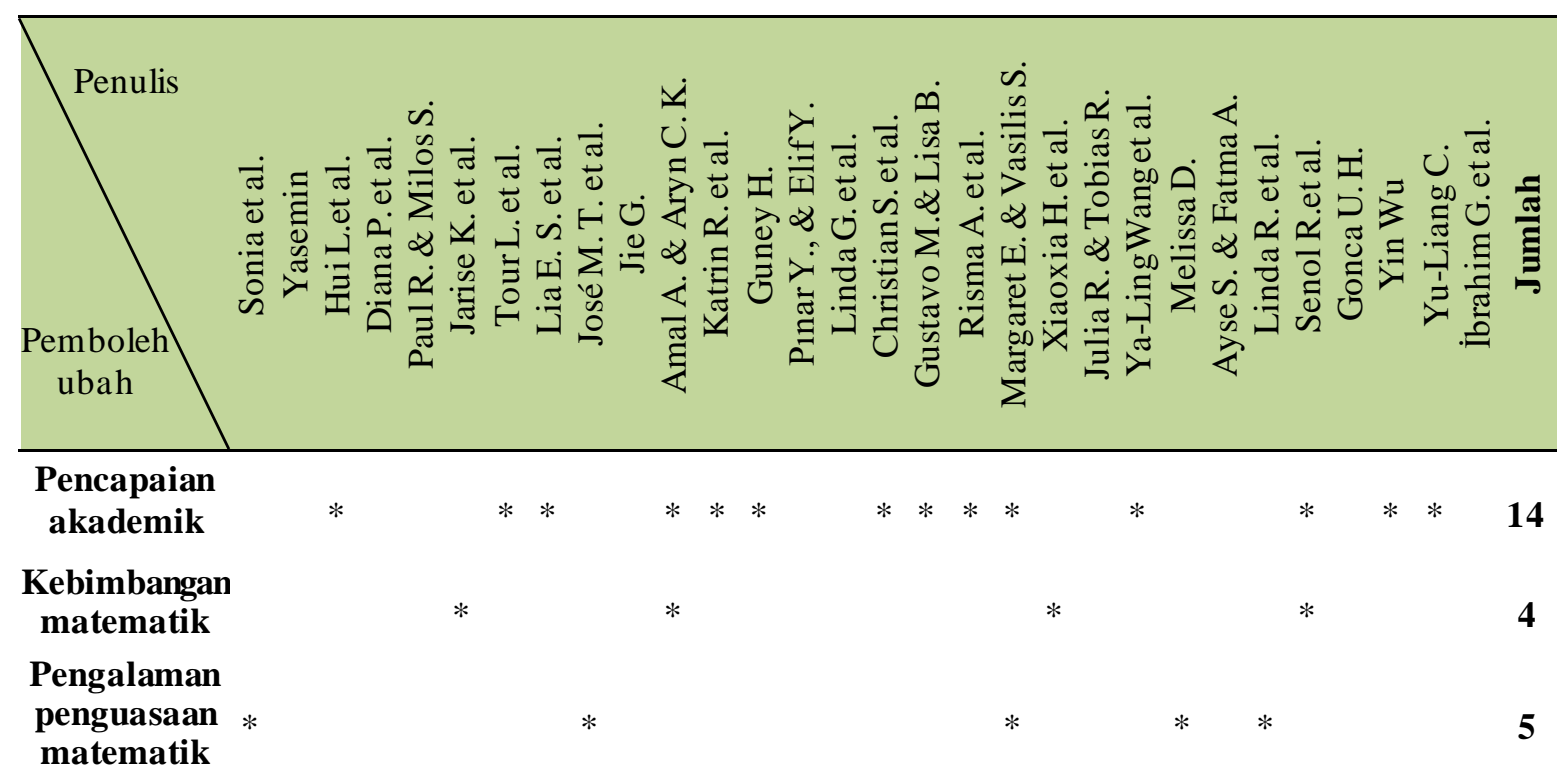




\begin{tabular}{|c|c|c|c|c|c|c|c|c|c|}
\hline $\begin{array}{c}\text { Kemahiran } \\
\text { berfikir }\end{array}$ & $*$ & & & $* \quad *$ & & & & & 3 \\
\hline Sikap & & & $*$ & & & $*$ & & & 3 \\
\hline $\begin{array}{c}\text { Sokongan } \\
\text { guru }\end{array}$ & & & & $*$ & & & * * & & 3 \\
\hline $\begin{array}{c}\text { Efikasi } \\
\text { kendiri guru }\end{array}$ & & & & & $*$ & & & $*$ & 2 \\
\hline Jantina & & & & & & * & & & * 2 \\
\hline Jenis sekolah & & & & & & * & & & * 2 \\
\hline $\begin{array}{c}\text { Kebolehan } \\
\text { guru }\end{array}$ & $* *$ & & & $*$ & & & & & 3 \\
\hline Kepercayaan & $*$ & $*$ & $*$ & & & & & & 3 \\
\hline $\begin{array}{c}\text { Keyakinan } \\
\text { diri }\end{array}$ & $*$ & & * & & & & * & & 4 \\
\hline $\begin{array}{l}\text { Status sosio- } \\
\text { ekonomi }\end{array}$ & $*$ & & & & & & * & & 2 \\
\hline $\begin{array}{c}\text { Kaedah } \\
\text { pembelajaran }\end{array}$ & $*$ & & & & & & & & 1 \\
\hline
\end{tabular}

Pemboleh ubah perkaitan dalam kajian efikasi kendiri pelajar terhadap matematik ini didapati daripada faktor diri sendiri, guru, sekolah dan persekitaran. Kemahiran berfikir, sikap, jantina, kepercayaan diri dan keyakinan diri merupakan pemboleh ubah yang boleh dikaitkan dengan faktor dalaman, manakala status sosio-ekonomi dan kaedah pembelajaran menunjukkan faktor persekitaran yang dikaji bersama dengan efikasi kendiri pelajar. Terdapat juga faktor guru ditemui dalam analisis ini seperti sokongan guru (King-Sears \& Strogilos, 2020; Usta, 2016; Wu, 2016), efikasi kendiri guru (Chang, 2015; Sarac, 2017) dan kebolehan guru mengajar matematik (Kaskens et al., 2020; King-Sears \& Strogilos, 2020; Regier \& Savic, 2020).

Berdasarkan ulasan sorotan kajian literatur bersistematik, kajian mendapati terdapat pelbagai trend penyelidikan kajian lepas mengenai efikasi kendiri pelajar dalam matematik. Trend penyelidikan tersebut telah dilihat melalui negara kajian, tahun penerbitan dan pemboleh ubah perkaitan yang digunakan bersama-sama dengan faktor efikasi kendiri pelajar dalam kajian mereka. Daripada analisis trend yang telah dilakukan, semakin banyak penyelidikan efikasi kendiri pelajar terhadap matematik ini dijalankan. Ia dapat menampung kekurangan kajian terhadap faktor ini pada beberapa tahun sebelumnya.

Trend negara kajian dapat dilihat bahawa Amerika Syarikat dan Turkey adalah negara yang paling mempunyai bilangan artikel kajian yang tertinggi untuk kajian efikasi kendiri pelajar terhadap matematik. Negara-negara lain boleh dijadikan sebagai jurang untuk menjalankan kajian terhadap faktor ini di masa hadapan. Manakala bagi trend pemboleh ubah perkaitan pula menunjukkan pencapaian akademik pelajar membantu menjelaskan tahap efikasi kendiri pelajar. Ia dibuktikan dengan faktor tertinggi yang dikaji bersama-sama dengan efikasi kendiri pelajar. Pengkaji pada masa akan datang boleh menjadikan ianya sebagai rujukan dimana mengkaji faktor lain yang boleh dikaitkan dengan efikasi kendiri pelajar seperti status sosio-ekonomi, strategi pembelajaran, tingkah laku, sikap dan keperitan. 


\section{Kesimpulan}

Kajian ini mendapati bahawa trend kajian bagi faktor efikasi kendiri pelajar terhadap matematik boleh diperoleh dengan mengkaji trend tahun kajian, trend negara kajian dan trend pemboleh ubah perkaitan. Ini menunjukkan bahawa efikasi kendiri merupakan faktor yang terkenal dan sering dikaji termasuk dalam pendidikan matematik. Kajian ini juga memberi peluang untuk menggunakan pangkalan data sebaik mungkin dalam pencarian artikel yang berkaitan. Penulisan analisis trend penyelidikan ini diharapkan dapat membantu mana-mana individu yang ingin mendapatkan maklumat agar dapat menganalisis artikel-artikel mengenai efikasi kendiri pelajar bagi tujuan penyelidikan dan lain-lain. Selain itu, diharap penyelidik yang akan datang membantu untuk perkembangan pengetahuan dan peningkatan tahap efikasi kendiri seseorang terutamanya dalam konteks pendidikan di Malaysia. Kajian ini juga dijangka dapat memberi idea untuk menganalisis pengaruh faktor lain terhadap efikasi kendiri pelajar dalam matematik. Kajian pada masa akan datang dicadangkan agar lebih banyak trend analisis penyelidikan yang mengukur tahap efikasi kendiri pelajar agar dapat membantu kecemerlangan pelajar dalam sistem pendidik terutamanya dalam kursus matematik. Antara idea yang boleh dikembangkan adalah trend ciri-ciri peserta kajian, trend jenis artikel terbitan, trend metodologi kajian dan trend jenis institusi pelajar.

\section{Rujukan}

Aksu, Z. \& Kul, Ü. (2019). The Mediating Role of Mathematics Teaching Efficacy on the Relationships between Pedagogical Content Knowledge and Mathematics Teaching Anxiety. SAGE Open 9(3), 1-10. https://doi.org/10.1177/21582440198710

Alhadabi, A., \& Karpinski, A. C. (2020). Grit, self-efficacy, achievement orientation goals, and academic performance in University students. International Journal of Adolescence and Youth, 25(1), 519-535. https://doi.org/10.1080/02673843.2019.1679202

Bandura, A. (1995). Comments on the Crusade against the Causal Efficacy of Human Thought. Journal of Behavior Therapy and Experimental Psychiatry, 26(3), 179-190.

Chang, Y. L. (2015). Examining relationships among elementary mathematics teachers' efficacy and their students' mathematics self-efficacy and achievement. Eurasia Journal of Mathematics, Science and Technology Education, 11(6), 1307-1320. https://doi.org/10.12973/eurasia.2015.1387a

Chelberg, K. \& Bosman, L (2020). American Indian college student mentoring: A study to measure changes in self-efficacy. Education Sciences 10(2), 1-13. https://doi.org/10.3390/educsci10020038

Deringöl, Y. (2020). Middle school students' perceptions of their self-efficacy in visual mathematics and geometry: a study of sixth to eighth grade pupils in Istanbul province, Turkey. International Journal of Primary, Elementary and Early Years Education, 48(8),1012-1023. https://doi.org/10.1080/03004279.2019.1709527

Echeverría Castro, S. B., Sotelo Castillo, M. A., Acosta Quiroz, C. O. \& Barrera Hernández, L. F. (2020). Measurement Model and Adaptation of a Self-Efficacy Scale for Mathematics in University Students. SAGE Open, 10(1), 1-10. https://doi.org/10.1177/2158244019899089

Gao, J. (2020). Sources of Mathematics Self-Efficacy in Chinese Students: a Mixed-Method Study with Q-Sorting Procedure. International Journal of Science and Mathematics Education, 18(4), 713-732. https://doi.org/10.1007/s10763-019-09984-1

Gregory, L., Villarosa, A. R., Ramjan, L. M., Hughes, M., O'Reilly, R., Stunden, A., Daly, M., et al. (2019). The influence of mathematics self-efficacy on numeracy performance in first-year nursing students: A quasi-experimental study. Journal of Clinical Nursing, 28(19-20), 3651-3659. https://doi.org/10.1111/jocn.14963

Grigg, S., Perera, H. N., McIlveen, P. \& Svetleff, Z. (2018). Relations among math self efficacy, interest, intentions, and achievement: A social cognitive perspective. Contemporary Educational Psychology, 53, 73-86. 
https://doi.org/10.1016/j.cedpsych.2018.01.007

Güneş, İ., Özsoy-Güneş, Z., Derelioğlu, Y. \& Kırbaşlar, F. G. (2015). Relations between Operational Chemistry and Physics Problems Solving Skills and Mathematics Literacy Self-efficacy of Engineering Faculty Students. Procedia - Social and Behavioral Sciences 174, 457-463. https://doi.org/10.1016/j.sbspro.2015.01.689

Haciomeroglu, G. (2019). The relationship between elementary students' achievement emotions and sources of mathematics self-efficacy. International Journal of Research in Education and Science, 5(2): 548-559.

Hamid, H. A., Baharum, M. \& Sarkowi, A. (2020). Pengaruh efikasi kendiri terhadap motivasi dan pencapaian akademik siswa pendidik. Jurnal IPDA 26, 104-113. https://103.8.145.246/index.php/ipda/article/view/8209

Huang, X., Zhang, J. \& Hudson, L. (2019). Impact of math self-efficacy, math anxiety, and growth mindset on math and science career interest for middle school students: the gender moderating effect. European Journal of Psychology of Education 34(3), 621-640. https://doi.org/10.1007/s10212-018-0403-Z

Karabulut-Ilgu, A., Jaramillo Cherrez, N., \& Jahren, C. T. (2018). A Systematic Review of Research on the Flipped Learning Method in Engineering Education. British Journal of Educational Technology, 49, 398-411. https://doi.org/10.1111/bjet.12548

Kaskens, J., Segers, E., Goei, S. L., van Luit, J. E. H., \& Verhoeven, L. (2020). Impact of Children's math self-concept, math self-efficacy, math anxiety, and teacher competencies on math development. Teaching and Teacher Education, 94, 103096, 1-14. https://doi.org/10.1016/j.tate.2020.103096

King-Sears, M. E., \& Strogilos, V. (2020). An exploratory study of self-efficacy, school belongingness, and co-teaching perspectives from middle school students and teachers in a mathematics co-taught classroom. International Journal of Inclusive Education, 24(2), 162-180. https://doi.org/10.1080/13603116.2018.1453553

Li, H., Liu, J., Zhang, D., \& Liu, H. (2020). Examining the relationships between cognitive activation, self-efficacy, socioeconomic status, and achievement in mathematics: A multi-level analysis. British Journal of Educational Psychology, (19), 1-26.

https://doi.org/10.1111/bjep.12351

Liu, T., Chen, X., Liu, M., Zhang, Y., Xin, T., \& Wang, Y. (2020). The effects of children's selfeducational aspiration and self-efficacy on mathematics achievement: A moderated chained mediation model. Anales de Psicologia, 36(2), 262-270. https://doi.org/10.6018/analesps.366621

Livers, S. D., Zelkowski, J., Harbour, K. E., McDaniel, S. C. \& Gleason, J. (2020). An Examination of the Relationships of Mathematics Self-Efficacy and Teaching Practices among Elementary, Secondary, and Special Education Educators. Investigations in Mathematics Learning 12(2), 96109.

https://doi.org/10.1080/19477503.2019.1670891

Mohd, A. B., Nawawi, A. B. M. \& Ismail, D. S. N. B. (2017). Tahap Efikasi Guru Dan Hubungannya Dengan Pencapaian Sekolah Di Sekolah-Sekolah Menengah Dalam Daerah Bachok. Proceedings of the ICECRS 1(1), 312-326. https://doi.org/10.21070/picecrs.v1i1.500

Morán-Soto, G., \& Benson, L. (2018). Relationship of mathematics self-efficacy and competence with behaviors and attitudes of engineering students with poor mathematics preparation. International Journal of Education in Mathematics, Science and Technology, 6(3), 200-220. https://doi.org/10.18404/ijemst.428165

Nirwana, S. R. A., Tiro, M. A. \& Sanusi, W. (2018). Pengaruh Kemampuan Berpikir Divergen Dan Efikasi Diri Terhadap Prestasi Belajar Matematika Melalui Kemandirian Belajar Siswa Kelas VIII SMP Negeri Galesong Utara, Kabupaten Takalar. Prosiding Seminar Nasional VARIANSI 2018, 140-161.

Perera, H. N. \& John, J. E. (2020). Teachers' self-efficacy beliefs for teaching math: Relations with teacher and student outcomes. Contemporary Educational Psychology 61, 101842. https://doi.org/10.1016/j.cedpsych.2020.101842 
DOI: https://doi.org/10.47405/mjssh.v5i12.570

Rakoczy, K., Pinger, P., Hochweber, J., Klieme, E., Schütze, B., \& Besser, M. (2019). Formative assessment in mathematics: Mediated by feedback's perceived usefulness and students' selfefficacy. Learning and Instruction, 60, 154-165. https://doi.org/10.1016/j.learninstruc.2018.01.004

Recber, S., Isiksal, M., \& Koc, Y. (2017). Investigating Self-Efficacy, Anxiety, Attitudes and Mathematics Achievement Regarding Gender and School Type. Anales de Psicología, 34(1), 4151. https://doi.org/10.6018/analesps.34.1.229571

Regier, P., \& Savic, M. (2020). How teaching to foster mathematical creativity may impact student self-efficacy for proving. Journal of Mathematical Behavior, 57(September 2018), 100720. https://doi.org/10.1016/j.jmathb.2019.100720

Roick, J. \& Ringeisen, T. (2018). Students' math performance in higher education: Examining the role of self-regulated learning and self-efficacy. Learning and Individual Differences 65(September 2016): 148-158. https://doi.org/10.1016/j.lindif.2018.05.018

Sandilos, L. E., Baroody, A. E., Rimm-Kaufman, S. E., \& Merritt, E. G. (2020). English learners' achievement in mathematics and science: Examining the role of self-efficacy. Journal of School Psychology, 79(June 2018), 1-15. https://doi.org/10.1016/j.jsp.2020.02.002

Sarac, A.-T. F. (2017). The Relationship between Teacher Efficacy, and Students' Trigonometry SelfEfficacy and Achievement. International Journal for Mathematics Teaching and Learning, 18(1), 66-83.

Schöber, C., Schütte, K., Köller, O., McElvany, N., \& Gebauer, M. M. (2018). Reciprocal effects between self-efficacy and achievement in mathematics and reading. Learning and Individual Differences, 63(January 2017), 1-11. https://doi.org/10.1016/j.lindif.2018.01.008

Sheu, H. Bin, Lent, R. W., Miller, M. J., Penn, L. T., Cusick, M. E. \& Truong, N. N. (2018). Sources of self-efficacy and outcome expectations in science, technology, engineering, and mathematics domains: A meta-analysis. Journal of Vocational Behavior 109, 118-136. https://doi.org/10.1016/j.jvb.2018.10.003

Tustyaningsih, Y., Sulistyono, B. A., \& Jatmiko (2017). Hubungan Self Efficacy Dengan Kemampuan Matematika Siswa Kelas XI SMK PGRI 1 Kediri. Journal of Simki, 1-10.

Tomás, J. M., Gutiérrez, M., Georgieva, S. \& Hernández, M. (2020). The effects of self-efficacy, hope, and engagement on the academic achievement of secondary education in the Dominican Republic. Psychology in the Schools 57(2): 191-203. https://doi.org/10.1002/pits.22321

Usta, H. G. (2016). Analysis of student and school level variables related to mathematics self-efficacy level based on PISA 2012 results for China-Shanghai, Turkey, and Greece. Educational Sciences: Theory \& Practice, 16(4), 1297-1323. https://doi.org/10.12738/estp.2016.4.0283

Wang, Y. L., Liang, J. C., Lin, C. Y., \& Tsai, C. C. (2017). Identifying Taiwanese junior-high school students' mathematics learning profiles and their roles in mathematics learning self-efficacy and academic performance. Learning and Individual Differences, 54, 92-101.

https://doi.org/10.1016/j.lindif.2017.01.008

Wu, Y. (2016). Universal Beliefs and Specific Practices: Students' Math Self-Efficacy and Related Factors in the United States and China. International Education Studies, 9(12), 61. https://doi.org/10.5539/ies.v9n12p61

Yıldız, P., Çiftçi, S. K., \& Özdemir, İ. E. Y. (2019). Mathematics self-efficacy beliefs and sources of self-efficacy: A Descriptive Study with two Elementary School Students. International Journal of Progressive Education, 15(3), 194-206. https://doi.org/10.29329/ijpe.2019.193.14

Zientek, L. R., Fong, C. J. \& Phelps, J. M. (2019). Sources of self-efficacy of community college students enrolled in developmental mathematics. Journal of Further and Higher Education 43(2): $183-200$. https://doi:10.1080/0309877X.2017.1357071 
DOI: https://doi.org/10.47405/mjssh.v5i12.570

Zuya, H. E., Kwalat, S. K. \& Attah, B. G. (2016). Pre-Service Teachers' Mathematics Self-Efficacy and Mathematics Teaching Self-Efficacy. Journal of Education and Practice 7(14): 93-98.

Zwart, D. P., Noroozi, O., Van Luit, J. E. H., Goei, S. L. \& Nieuwenhuis, A. (2020). Effects of Digital Learning Materials on nursing students' mathematics learning, self-efficacy, and task value in vocational education. Nurse Education in Practice 44, 102755.

https://doi.org/10.1016/j.nepr.2020.102755 